\title{
Effects of Hot Exhaust Gas Recirculation (EGR) on the Emission and Performance of a Single-Cylinder Diesel Engine
}

\author{
M. A. A Mossa ${ }^{*}$, A. A. Hairuddin, A. A. Nuraini, J. Zulkiple and \\ M. T. Hasyuzariza \\ Department of Mechanical and Manufacturing Engineering, Faculty of Engineering, \\ Universiti Putra Malaysia, 43400 UPM Serdang, Malaysia \\ "Email: memo.alprince41@ gmail.com
}

\begin{abstract}
With the increment in global demand for energy, there is a need to reduce vehicle emission, which is among the major causes of air pollution around the world. In order to reduce the emissions levels, this study focuses on the effects of hot exhaust gas recirculation (EGR) system on the performance and emissions of a direct injection (DI) diesel engine. The performance studied includes engine power, torque, brake mean effective pressure, fuel consumption and the exhaust emission. The engine used in this study was a single-cylinder, four-stroke engine with an air-cooled system at a rated speed of $3600 \mathrm{rpm}$ with displacement of 0.219 litres. The engine was operated at varying speeds of 1600 to $3600 \mathrm{rpm}$ with different percentages of EGR $(5 \%, 7 \%, 10 \%$ and $15 \%)$. Based on the results, it was shown that EGR had decreased the engine brake power and torque while increasing fuel consumption at the same time. The engine with EGR has reduced the emission level of $\mathrm{NO}_{\mathrm{x}}$ from 800 to $240 \mathrm{ppm}$ and $\mathrm{CO}_{2}$, from $9 \%$ to $4 \%$, while increasing the $\mathrm{CO}$ from $2 \%$ to $4 \%$ and UHC from 10 to $100 \mathrm{ppm}$. Hence, it was concluded that low emission level of $\mathrm{NO}_{x}$ and $\mathrm{CO}_{2}$ could be obtained using EGR as it can be used to improve the emission level of a homogeneous charge compression ignition (HCCI) even further in the extension of this study.
\end{abstract}

Keywords: EGR; performance; emissions; diesel engine; in-cylinder pressure.

\section{NOMENCLATURE}

$\begin{array}{ll}\text { DI } & \text { direct injection } \\ \text { EGR } & \text { exhaust gas recirculation } \\ \text { EGT } & \text { exhaust gas temperature } \\ \text { TE } & \text { thermal efficiency } \\ \text { IMEP } & \text { indicated mean effective pressure } \\ \text { BTE } & \text { brake thermal efficiency } \\ \text { B.P } & \text { brake power } \\ \text { SFC } & \text { specific fuel consumption } \\ \text { HC } & \text { hydrocarbon } \\ \text { CO } & \text { monoxide } \\ \text { NOx } & \text { nitric oxides } \\ \text { CO2 } & \text { carbon dioxide }\end{array}$




\section{INTRODUCTION}

There is a growing concern in the well-being of the human population and environment due to the alarming level of vehicular greenhouse gas emission in developing and developed countries worldwide. The emission from engine depends mainly on the engine's operating system involving load, speed, type of fuel, exhaust gas recirculation (EGR), fuel quality and fuel injection strategy as stated by Kumar and Saravanan [1]. The diesel engine compression Ignition (CI) is universally popular since it can improve fuel economy, run on a higher compression ratio, low in maintenance cost and has a higher torque compared to the spark ignition (SI) engine. The emission of the diesel engine is less than that of the SI engine. EGR helps to improve the combustion in several unburned zones of the blend, which are burned again with the method by Khalilarya et al. [2]. Besides, this method is often applied to decrease engine's emission level. Literature review revealed many studies examining different modes, systems and biofuel to improve engine performance and reduce gas emission level [3]. A study by Mukesh et al. [4] has been conducted focusing on the use of EGR into the cylinders of a four-stroke diesel engine in an experimental study of the CI engine, which was modified to work with the EGR. The performance and emission rates of this engine were tested with different EGR rate and revealed $40 \%$ as the highest EGR percentage under variable load conditions, which had reduced the $\mathrm{NO}_{\mathrm{x}}$ emission level to $80 \%$ with EGR. Besides, a study by Gurumoorthy et al. [5] using different EGR ratio in a direct injection (DI) diesel engine to investigate the performance and emission levels of the engine reported that the use of EGR was able to decrease the emission level of the engine. Furthermore, a study by Manieniyan et al. [6] analysed the experimental work of EGR in CI engine using B20 biodiesel as the fuel with EGR on a diesel engine. The EGR was used at different rates $(5 \%, 10 \%, 15 \%$ and $20 \%)$. In the study, the smoke was increased to a high level when EGR was used, causing reduced oxygen inthe combustion chamber compared to a diesel engine and increasing the $\mathrm{CO}$ emission level. A study by Avinash Kumar et al. [7] on a CI engine with EGR fuelled with diesel to investigate the effects of different EGR charges on the exhaust emission from the engine demonstrated an effective system; however, the increase in specific fuel consumption (SFC) was observed by $10-15 \%$, whereas the EGR system had reduced NOx emission.

Moreover, a study by Hussain et al. [8] conducted on a four-stroke, two cylinders diesel engine at a constant speed of $1500 \mathrm{rpm}$ showed that the use of EGR had reduced the unburned hydrocarbon (UHC). In another study by Donepudi et al. [9] investigating the characteristics of a diesel engine's performance with biodiesel (palm stearin methyl ester) using EGR on a single cylinder engine at $1500 \mathrm{rpm}$ and water-cooled engine with a dynamometer, it was found that EGR had affected fuel consumption usage. Besides, the EGR was considered as the best way to decrease $\mathrm{NO}_{\mathrm{x}}$ emission. The best rate of EGR selected in the study was between 10-15\%. A study by Paykani et al. [10] had focused on the reduction of engine noise, $\mathrm{PM}$ and $\mathrm{NO}_{\mathrm{x}}$ emissions by investigating the effects of fuel injection pressure. The specific control of spray injection and air/fuel mixing is necessary to achieve complete combustion. The injection pressure is a critical factor in the fuel injection system and an important feature of the combustion process as it influences the level of exhaust emission and noise of the diesel engine. High injection pressure reduces fuel consumption with good atomisation, improves combustion and reduces smoke emission, whereas low injection pressure is required to decrease the noise at the low loads level. On the other hand, when combined with EGR and biodiesel, the emission of UHC and $\mathrm{CO}$ decrease with increased biodiesel percentage, and the increase in EGR flow can 
result in a higher $\mathrm{HC}$ and $\mathrm{CO}$ emission levels for diesel and COEE blend (Canola - oil ethyl ester).

The effects of the EGR range of injection timing have been investigated by Huang et al. [11]. The primary objective of the study was to examine the combustion engine's characteristics of progressive times of injection at different rates of EGR. The rate of EGR of more than $25 \%$ has resulted in increased emission (soot $\mathrm{UCH}$ and $\mathrm{CO}$ ), and when the ratio of EGR was more than $40 \%$, the $\mathrm{NO}_{\mathrm{x}}$ emission level was near zero. A study by $\mathrm{S}$ Saravanan [12] dealt with the EGR system and the need to reduce $\mathrm{CO}_{2}$ exhaust. The injection timing was observed to advance by $33 \%$ of decreased smoke density and increased $\mathrm{NO}_{\mathrm{x}}$ emission level by $20 \%$. The EGR result was decreased by $63 \%$ with $\mathrm{NO}_{\mathrm{x}}$ emission level with the increase in smoke. A study by Mohd et al. [13] had focused on effects of EGR technique and palm oil on the SFC, performance and emission levels. The experimental work used a multi-cylinder of the diesel engine at a constant engine speed of $2500 \mathrm{rpm}$ under full load. The result showed that when using EGR, the NOx emission level reduced along with the exhaust temperature, but increased in SFC and other emission levels. A study by Pratik et al. [14] investigated the effects of using different rates of EGR system on the engine emission levels. The study was done by passing the exhaust gas from the venturi meter regulated with EGR valve to reduce $\mathrm{NO}_{\mathrm{x}}$ emission level.

The important aim of this study is to evaluate the suitability of EGR for CI engine. It was shown that when used the EGR system, the NOx emission level reduced to $64.75 \%$ with decreased $\mathrm{CO}$ emission level. Meanwhile, the HC increased when using the EGR system. A study by Maroa et al. [15] had focused on the effects of using the EGR system on emission and performance of diesel engine. So, this present study investigated the use of EGR to decrease the NOx emission level. In this study, commercial diesel fuel was utilised to run the engine after reviewing many previous studies in this area using a diesel engine to compare the results obtained from using pure diesel fuel and EGR mainly to reduce $\mathrm{NO}_{\mathrm{x}}$ and $\mathrm{CO}_{2}$ emission levels. This study focused on solving the emission level problem from combustion chamber of diesel engine and investigated the combined effects of the EGR system in the diesel engine combustion on emission and performance, which were compared and analysed when the engine is operating on diesel fuel under different EGR rates $(5 \%, 7 \%, 10 \%$ and $15 \%)$. The increase in intake temperature was seen to reduce the air-to-fuel AFR ratio, leading to a decrease in brake thermal efficiency. The EGR controls the emission level of a diesel engine and influences the emissions levels of a DI diesel engine. So, this study could reduce $\mathrm{NO}_{\mathrm{x}}$ emission and $\mathrm{CO}_{2}$ emission levels.

\section{METHODOLOGY}

The engine used in this study was a single cylinder diesel engine, bore and stroke of 70 and $57 \mathrm{~mm}$, respectively, air-cooled with a rated speed of $3600 \mathrm{rpm}$ and displacement of 0.219 litres as shown in Table 2. The presented amount of EGR was controlled by a valve. The gas of the exhaust was recirculated in the stream of fresh air taken from the valve and mixed with the air from the inlet manifold before being sent to the cylinder. This study utilised diesel fuel, as shown in Table 1. Figure 1 displays the experimental setup where the engine was prepared with EGR and a preheater. The exhaust gas from the exhaust pipe was connected to the inlet manifold without cooling, therefore implying that the EGR was hot. The actual engine setup is shown in Figure 2. Since the previous study by Srinivasa et al. [16] using EGR with a diesel engine as an approach to reduce $\mathrm{NO}_{\mathrm{x}}$ emission level displayed an increased SFC, this study used EGR technique connected 
with diesel engine, while the recirculation part was with the exhaust gas along with the inlet air charge that helps to decrease $\mathrm{NO}_{x}$. This experiment was employed using waste cooking oil methyl ester blends with diesel fuel. The EGR system was required to develop the single cylinder of diesel engine, direct injection and water cooled engine. The EGR rates used were from $0 \%$ to $20 \%$, whereas the best engine characteristic was at the rate of $15 \%$ for all different fuel blends.

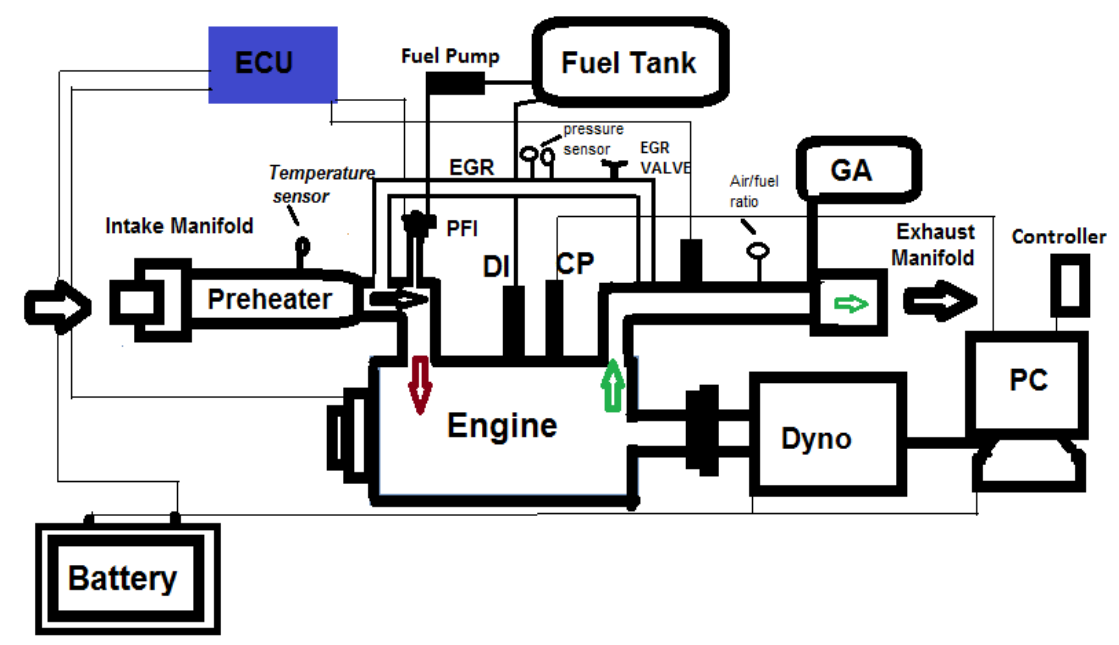

Figure 1. Engine with EGR set up.

Table 1. Typical characteristics of diesel fuel (Petron, 2015)

\begin{tabular}{lccc}
\hline No & Property & Unit & Value \\
\hline 1 & Density at $15^{\circ} \mathrm{C}$ & $\mathrm{Kg} / \mathrm{l}$ & 0.8314 \\
2 & Colour & $\mathrm{ASTM}$ & $\mathrm{L} 1.0$ \\
3 & Kinematic Viscosity at $40^{\circ} \mathrm{C}$ & $\mathrm{cSt}$ & 2.900 \\
4 & Flash Point ${ }^{\circ} \mathrm{C}$ & $\mathrm{PMCC}$ & 63.0 \\
5 & Sediments and water & Vol $\%$ & 0.00 \\
5 & Sulphur & $\mathrm{ppm}$ & 330 \\
6 & Cetane Number & - & 54.0 \\
7 & Copper Corrosion & 3 hrs. at $100{ }^{\circ} \mathrm{C}$ & $1 \mathrm{a}$ \\
8 & Lubricity HFRR @ $60^{\circ} \mathrm{C}$ Wear Scar diameter & Microns & 240 \\
9 & $\mathrm{CCR}$ on $10 \%$ Bottoms & Mass $\%$ & 0.04 \\
\hline
\end{tabular}

Table 2. Specifications of the engine.

\begin{tabular}{|c|c|c|}
\hline No & Classification & Specifications \\
\hline 1 & Type & $\begin{array}{l}\text { The vertical cylinder,4-cycle air- } \\
\text { cooled of diesel engine }\end{array}$ \\
\hline 2 & The combustion & DI \\
\hline 3 & Max power & $3.5 \mathrm{KW}$ \\
\hline 4 & The Rated speed of engine & 3600 RPM \\
\hline 5 & Displacement & $0.219 \mathrm{Ltr}$ \\
\hline 6 & Bore $\times$ stroke & $70 \times 57 \mathrm{Mm}$ \\
\hline 7 & Number of cylinders & one \\
\hline 8 & Sectors & $\begin{array}{l}\text { Agriculture, Genset, General Use } \\
\text { and Construction }\end{array}$ \\
\hline
\end{tabular}




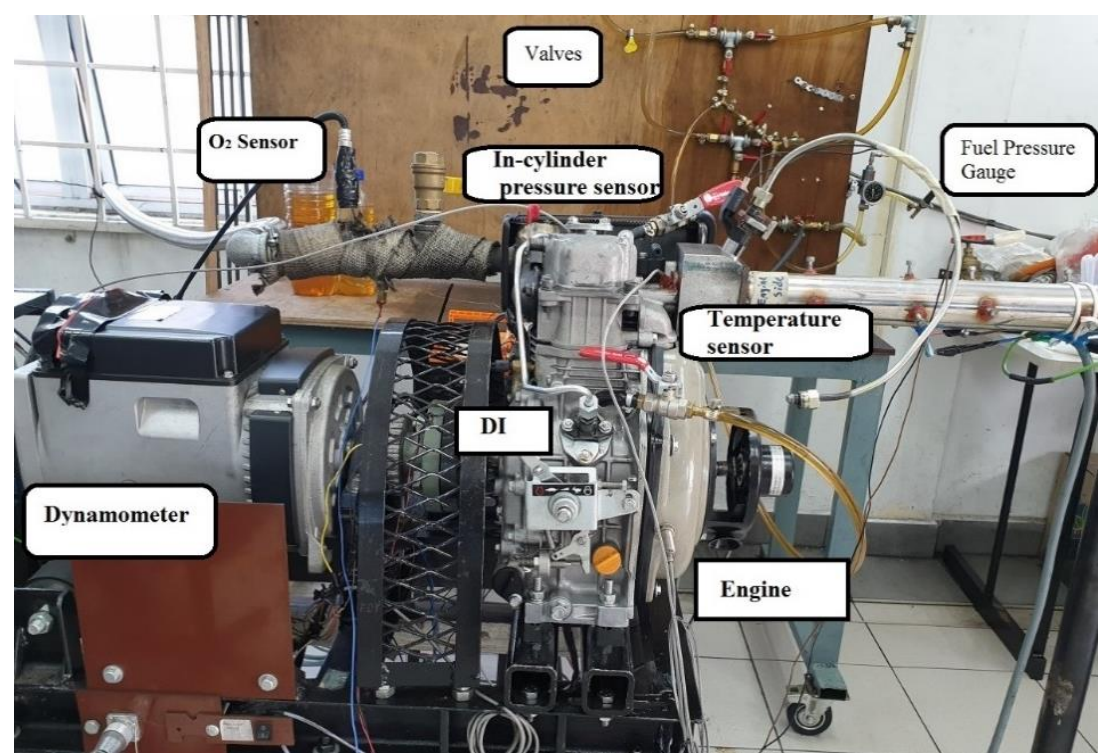

(a)

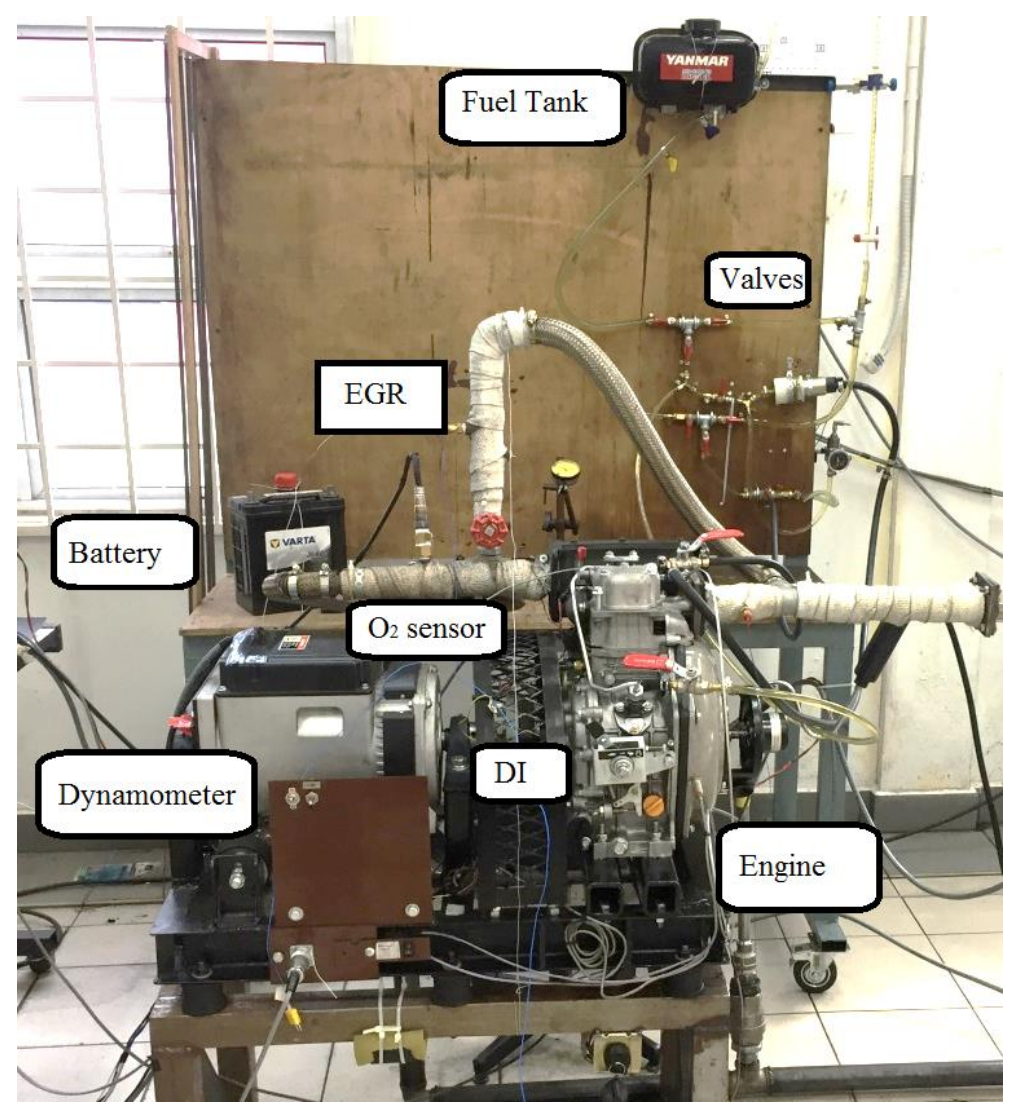

(b)

Figure 2: (a) Diesel engine and; (b) diesel engine with EGR.

The first step of the experimental work was achieved using a diesel engine at different engine speeds, which worked without EGR, while the engine loads were supplied in the step using a dynamometer. The engine was started and kept running for several minutes until it reached a stable condition and warmed up. The measurement of different parameters, namely BTE, B.P, BSFC was done by setting the engine at different 
engine speeds. The experiments were employed on the diesel engine with different speeds (from 1600 - 2600) with increment at every $200 \mathrm{rpm}$. The engine power, torque, temperatures, lambda $(\lambda)$, fuel consumption and emissions levels $\left(\mathrm{CO}, \mathrm{CO}_{2}, \mathrm{O}_{2}, \mathrm{NO}_{\mathrm{x}}\right.$ and UHC) were recorded. The second step of the experiment was achieved using the diesel engine in different speeds (from 1600 to $2600 \mathrm{rpm}$ ) with EGR at different rates (5\%, 7\%, $10 \%$, and 15\%). In addition, the chemical symbols of the combustion of diesel and air mixture produced in combustion chamber of engine by Kazuhiro et al. [17] are as shown below with the equation of diesel fuel:

$4 \mathrm{CH} 23+71 \mathrm{O} 2 \rightarrow 48 \mathrm{CO} 2+46 \mathrm{H} 2 \mathrm{O}$

\section{RESULTS AND DISCUSSIONS}

This study investigated the effects of EGR on emissions level of $\mathrm{CO}, \mathrm{CO}_{2}, \mathrm{NO}_{\mathrm{x}}, \mathrm{O}_{2}$ and UHC as shown in Figure 3. The engine yielded the highest $\mathrm{NO}_{\mathrm{x}}$ when the EGR was turned off. The $\mathrm{NO}_{\mathrm{x}}$ increased as the engine speed is increased from 1600 to $2600 \mathrm{rpm}$ as shown in Figure 3(c). This was mainly due to the higher oxygen content in diesel fuel, which led to the oxidisation of flame in the combustion chamber that further raised the combustion temperature and in turn increased the generation of $\mathrm{NO}_{\mathrm{x}}$ emission. Normally, $\mathrm{NO}_{\mathrm{x}}$ emission tends to significantly decrease in relation to a rise in EGR amount at different engine speeds. The emission of $\mathrm{NO}_{\mathrm{x}}$ reduced when the engine runs with EGR, as shown in Figure 3(c). On the other hand, the proportion of $\mathrm{CO}$ production for diesel fuel increased until $2600 \mathrm{rpm}$, and when the engine works with EGR, the CO emission increased compared to that without EGR. The $\mathrm{CO}$ was at the highest whenever the engine operated at a maximum rate of $15 \%$ EGR at all engine speeds, as shown in Figure 3(b). This was in line with other studies such as that by Verschaeren et al. [18] showing that when the engine used more than $25 \%$ EGR, the CO emission was quickly increased. The $\mathrm{CO} 2$ emission, on the other hand, decreases whenever the amount of EGR was increased. The $\mathrm{CO} 2$ was the lowest at maximum EGR of $15 \%$ at all engine speeds as in Figure 3(a). Thus, it has an opposite correlation with $\mathrm{CO}$, where the production of $\mathrm{CO} 2$ requires sufficient residence time for $\mathrm{CO}$ to be converted to $\mathrm{CO} 2$. If the residence time is not enough, the engine will produce more $\mathrm{CO}$, which is a harmful gas.

This result in $\mathrm{CO}$ emission was comparable to that of Huang, $\mathrm{H}$ Zhou [11]; when EGR was used, any $\mathrm{CO}$ that has not been converted yet will consume $\mathrm{O}_{2}$ from the fresh charge so that the $\mathrm{CO}$ can be converted to $\mathrm{CO}_{2}$. Hence, the $\mathrm{O}_{2}$ decreases when the EGR is implemented as shown in Figure 3(d). Usually, the diesel engine gives a low UHC emission when using diesel fuel. Every increase in percentage of EGR increases the rate of UHC compared to the engine without EGR as displayed in Figure 4(e). A study by Naik N S and Balakrisha [19] discussed the results of CO and UHC, which was up to 12.33 and $17.6 \%$ respectively, although $\mathrm{NO}_{x}$ emission levels were reduced up to $24.33 \%$.

The cylinder pressure was also investigated and compared with and without EGR rate for the different engine as shown in Figure 4. The cylinder pressure without EGR at full load was seen at a higher level where the peak pressure at this point was found to be 80 bar, demonstrating that the pressure increases with the increase in engine load. Full load with different EGR rates (5\%, 7\%, 10\% and 15\%) showed the cylinder pressure of 71.7 bars, 75.4 bars, 74.6 bars and 71.2 bars, respectively, as depicted in Figure 4(b)-4(e). 


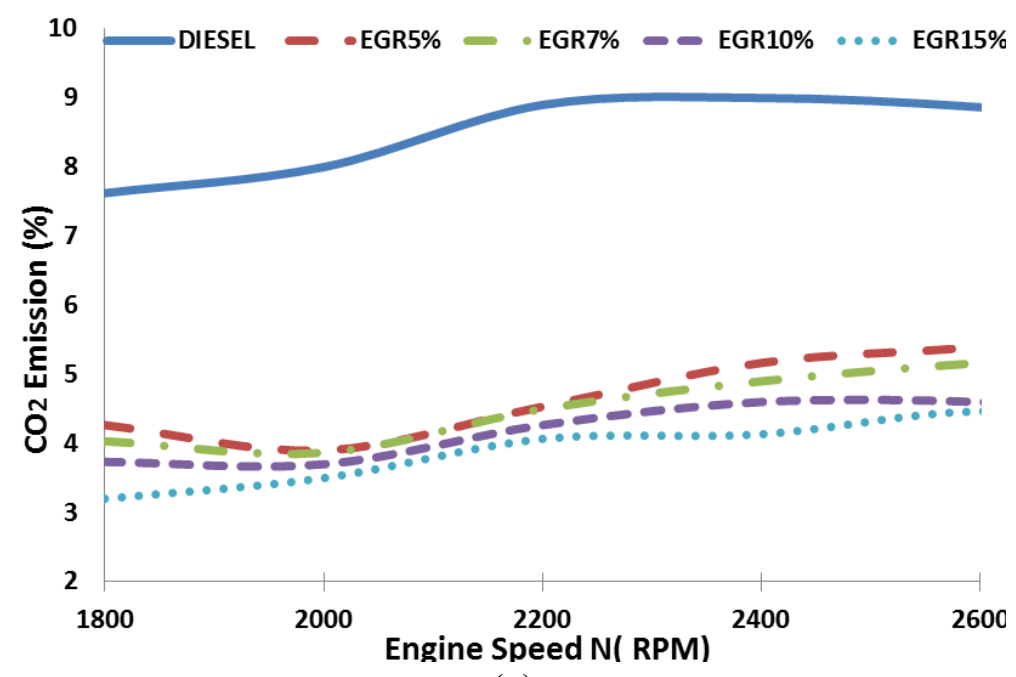

(a)

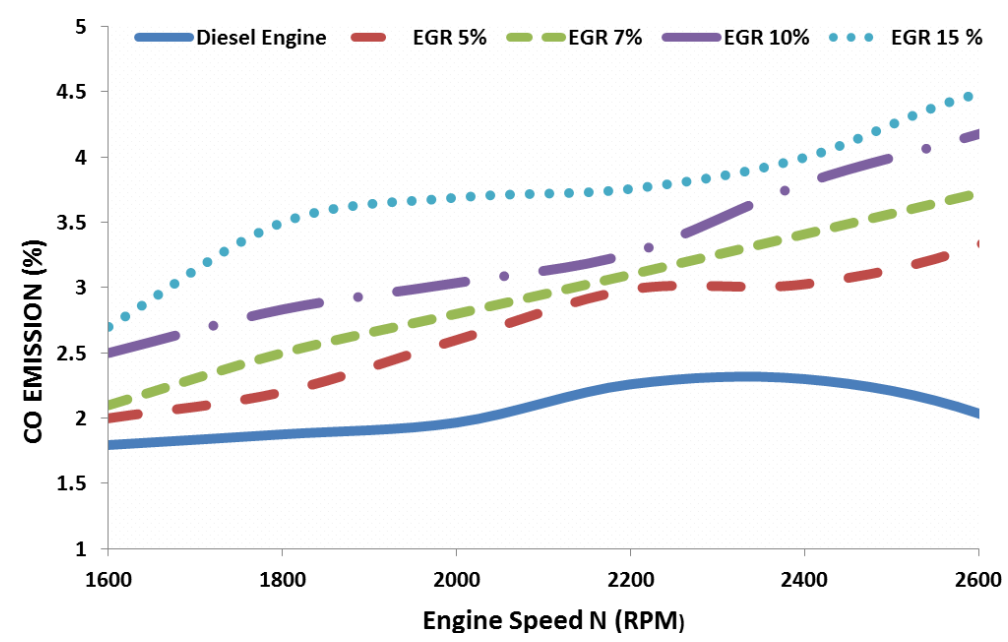

(b)

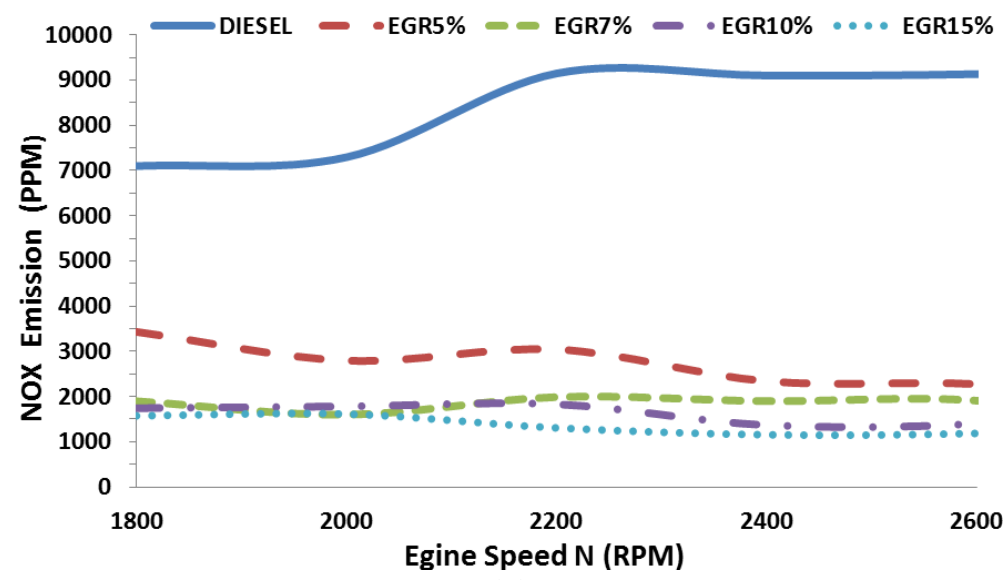

(c) 


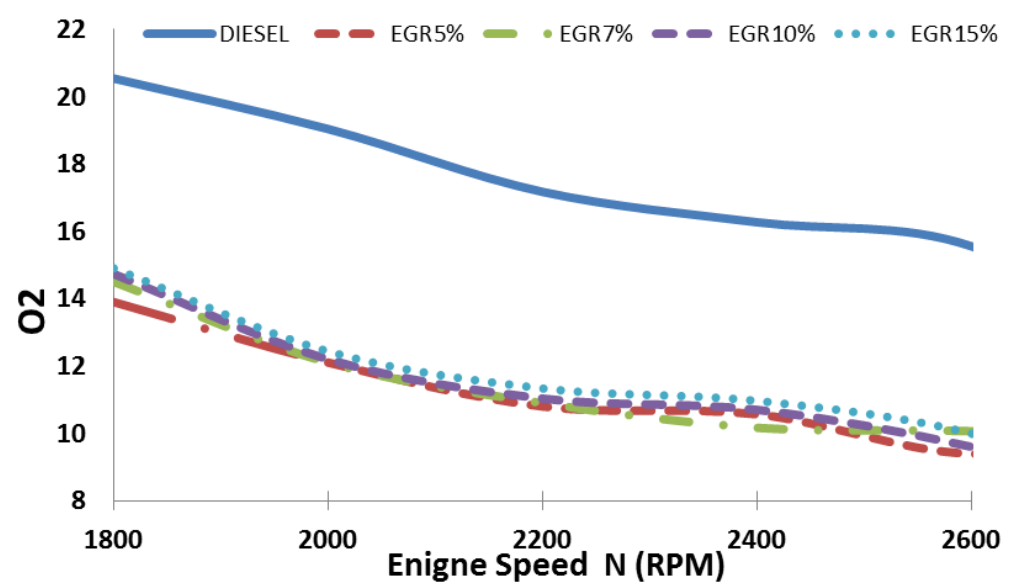

(d)

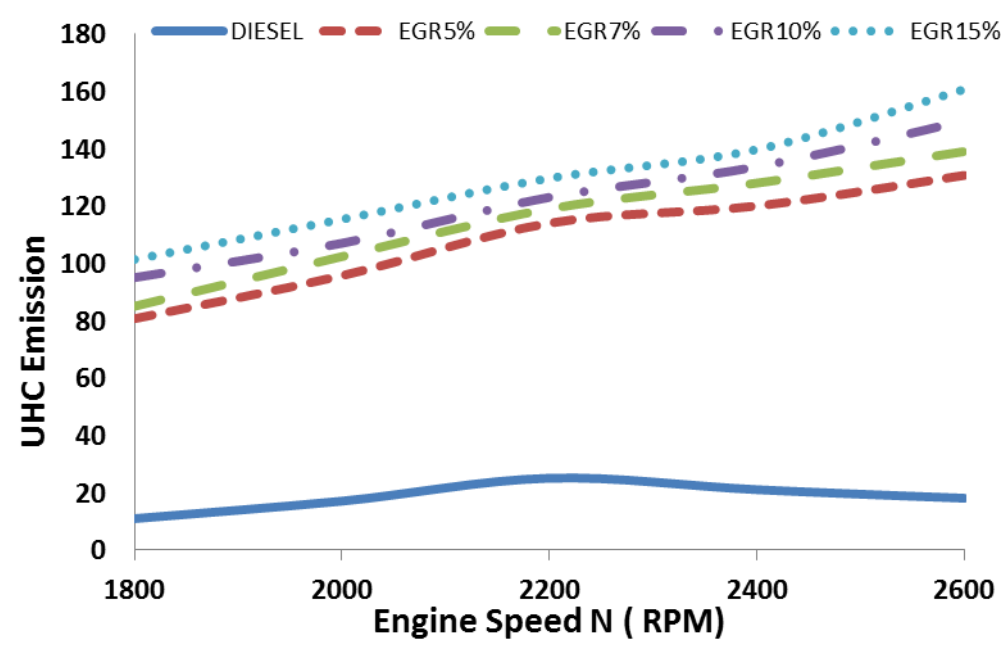

(e)

Figure 3. Emission levels of (a) $\mathrm{CO}$, (b) $\mathrm{CO}_{2}$, (c) $\mathrm{O}_{2}$, (d) $\mathrm{NO}_{\mathrm{x}}$ and; (e) $\mathrm{UHC}$ at different engine speed and EGR rates.

These results were due to EGR operation as heat absorbing factor, causing a decrease in blend temperature in the combustion process. Figure 4(f) presents the cylinder pressure at $2600 \mathrm{rpm}$ with different EGR rates. It shows that the cylinder pressure was higher when the EGR was not in use, and reduced whenever the EGR rate was increased. This was due to maximum temperature difference in the combustion chamber that reduces when the EGR was implemented. The result is in agreement with that discussed by Manieniyan [6] using EGR of 5\%,7\%, 10\% and 20\% in which the in-cylinder pressure reduced with the use of EGR. 


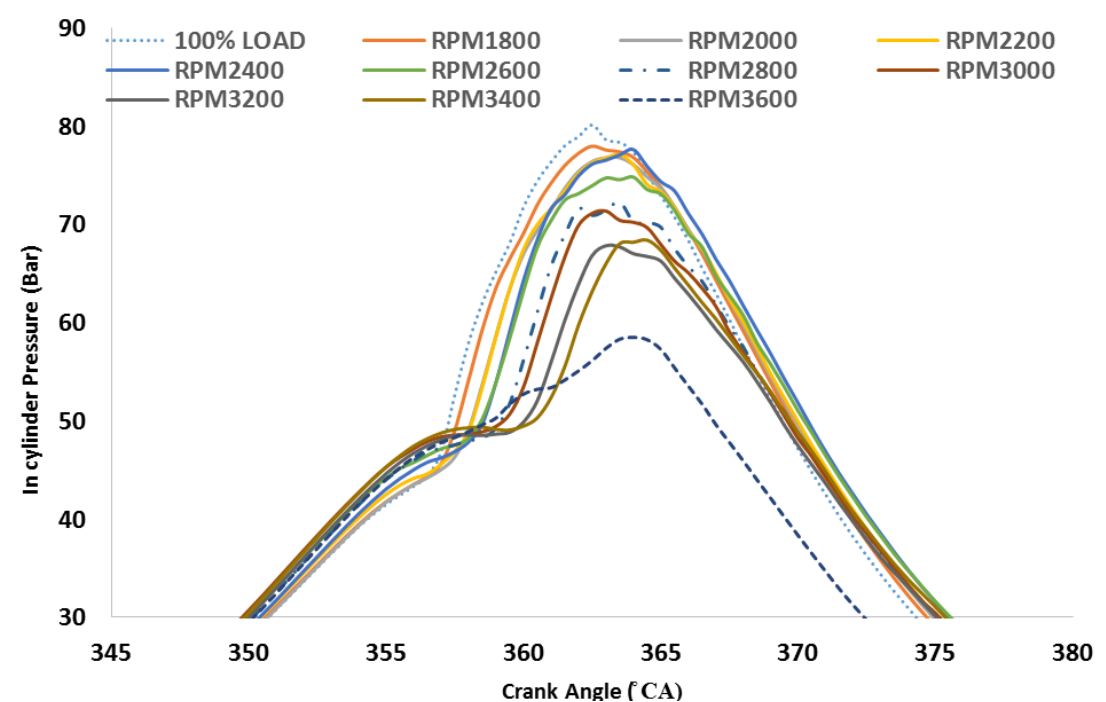

(a)
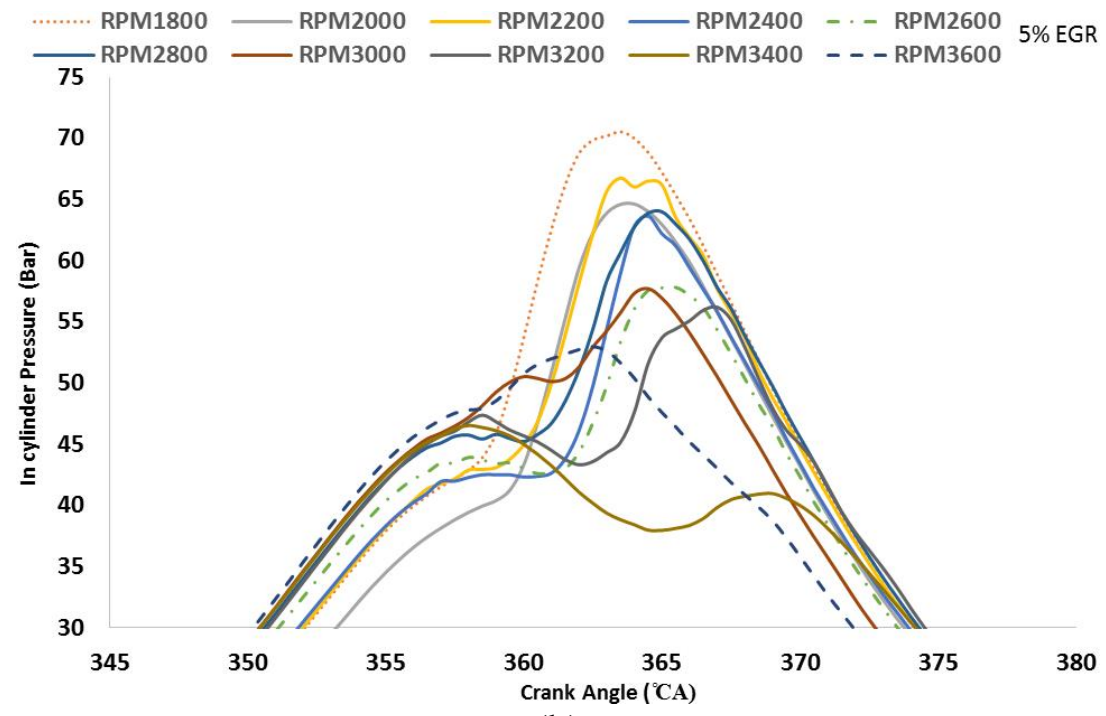

(b)

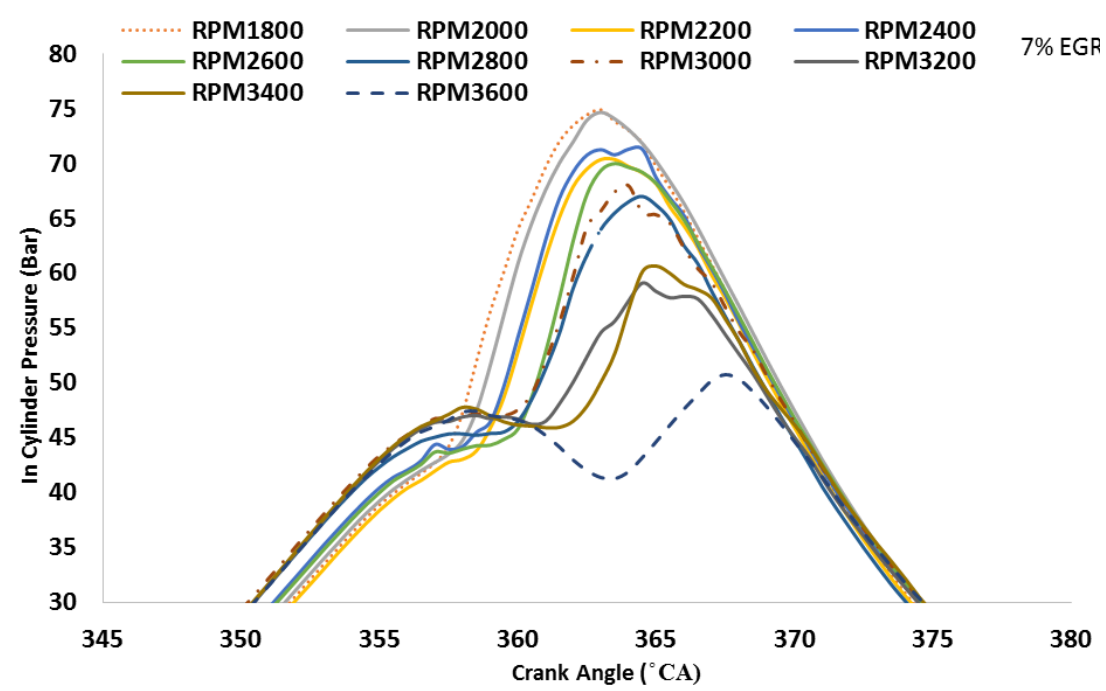

(c) 


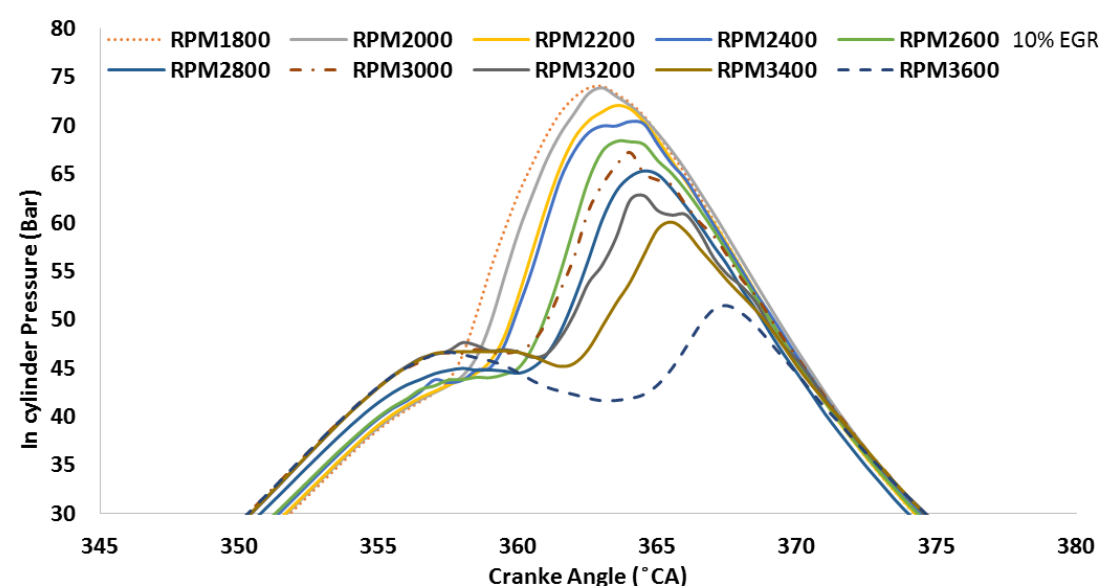

(d)

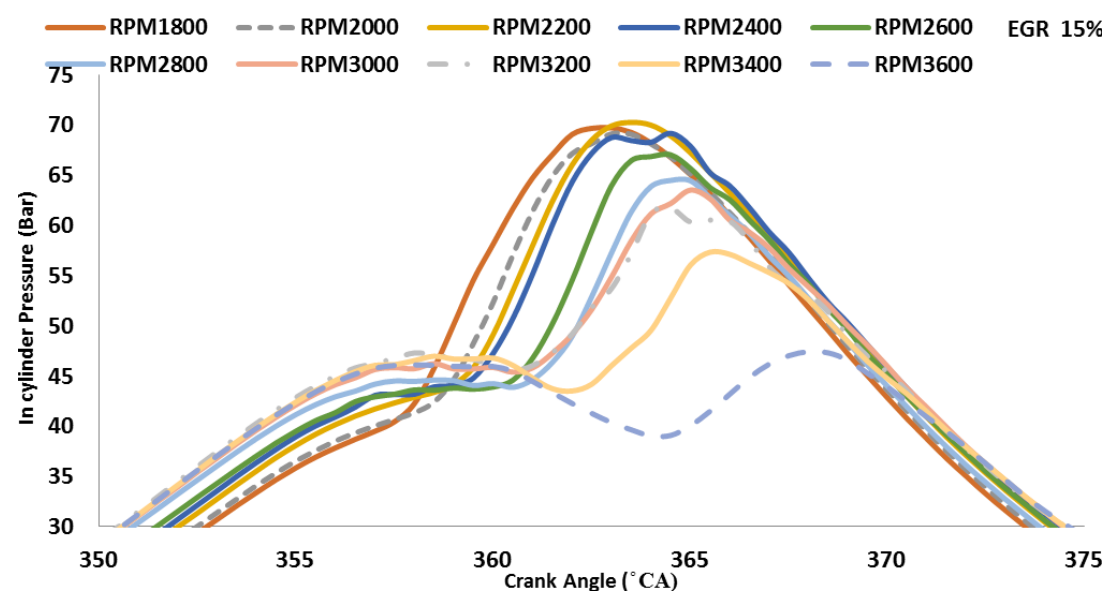

(e)

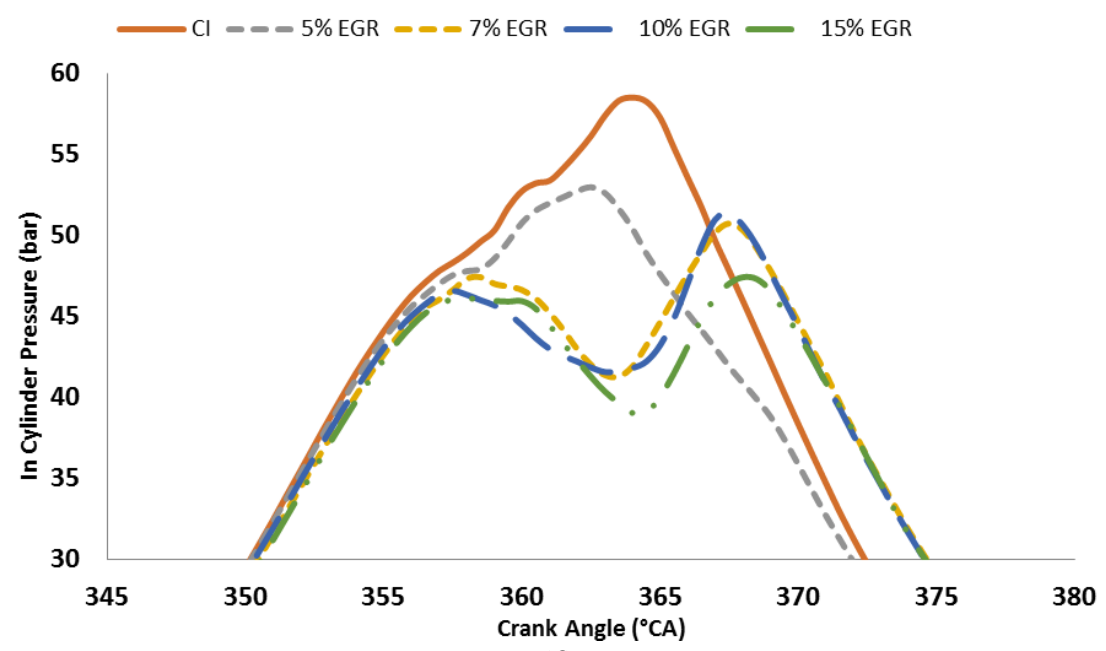

(f)

Figure 4. The in-cylinder pressure trace at different engine speeds and working with diesel fuel with and without EGR. (a) normal diesel, (b) 5\%, (c) 7\%, (d) 10\%, (e) 15\% and; (f) all rates.

Diesel engine with EGR system created a lower power compared to conditions where the EGR was not used at different engine speeds. Engine running without EGR 
could correspondingly reduce torque. The study on the torque of engine utilising diesel fuel has caused the result in Figure 5(a) where the torque was reduced from 10.7 N.m to 9.4 N.m when working with EGR. This study demonstrated a loss in torque and power in engine that could be affected by lower oxygen from the inlet amount through the combustion stroke. When the engine is working with EGR, the brake power was decreased from $2.1 \mathrm{~kW}$ to $1.75 \mathrm{KW}$ at low engine speed and when the engine speed increased, the power had also increased. So, at engine speed of $2600 \mathrm{rpm}$, the brake power decreased from $3.05 \mathrm{~kW}$ to $1.97 \mathrm{~kW}$ as shown in Figure 5(a).

The variation of a specific fuel consumption based on different engine speeds and different EGR rates was affected by engine load and speeds. It can be observed that BSFC was increased from $330 \mathrm{~g} . \mathrm{kw} / \mathrm{hr}$ to $445 \mathrm{~g} . \mathrm{kw} / \mathrm{hr}$ with the increase in engine speed and EGR as shown Figure 5(c). The results of this study confirmed that the diesel engine produced low SFC when no EGR was used. The increase in SFC was apparent as diesel engine with EGR has less energy than the normal diesel engine. Moreover, engine running on diesel fuel has higher brake power compared to diesel engine with EGR as shown in Figure 5(b). This study is comparable with that by R. Verschaeren [18] studying the effects of EGR on fuel consumption.

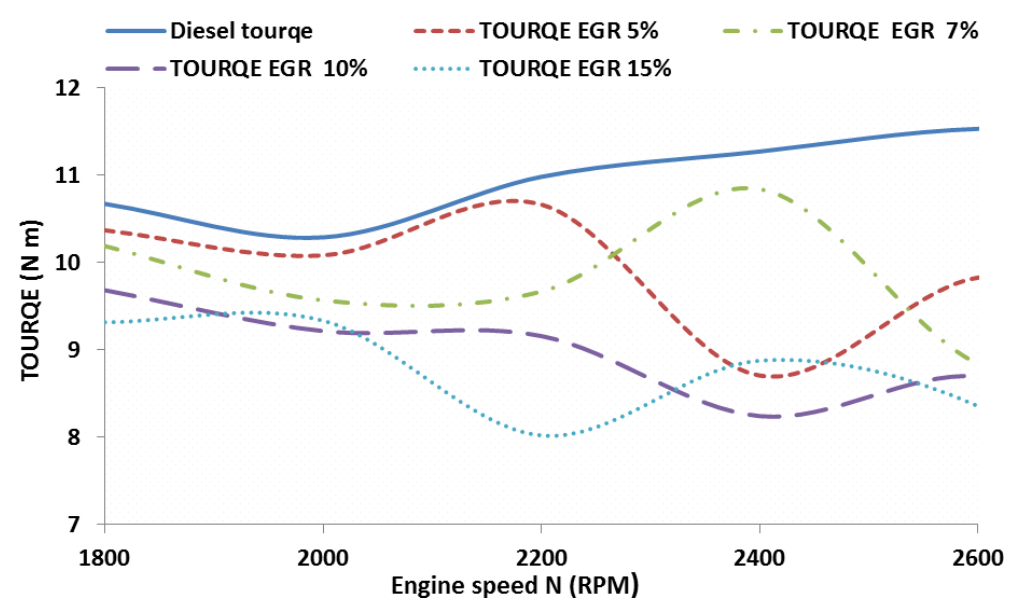

(a)

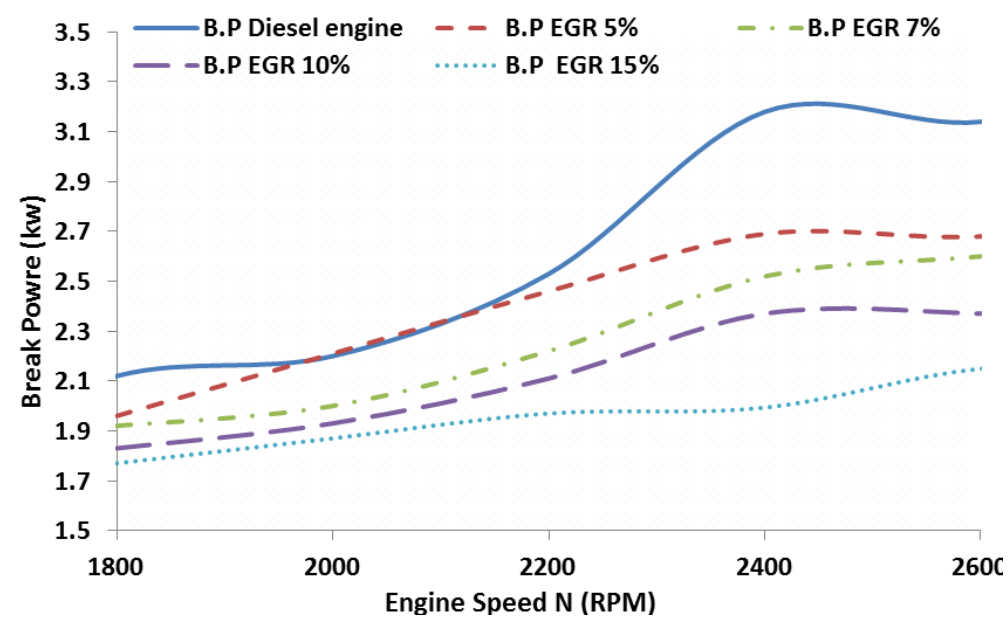

(b) 


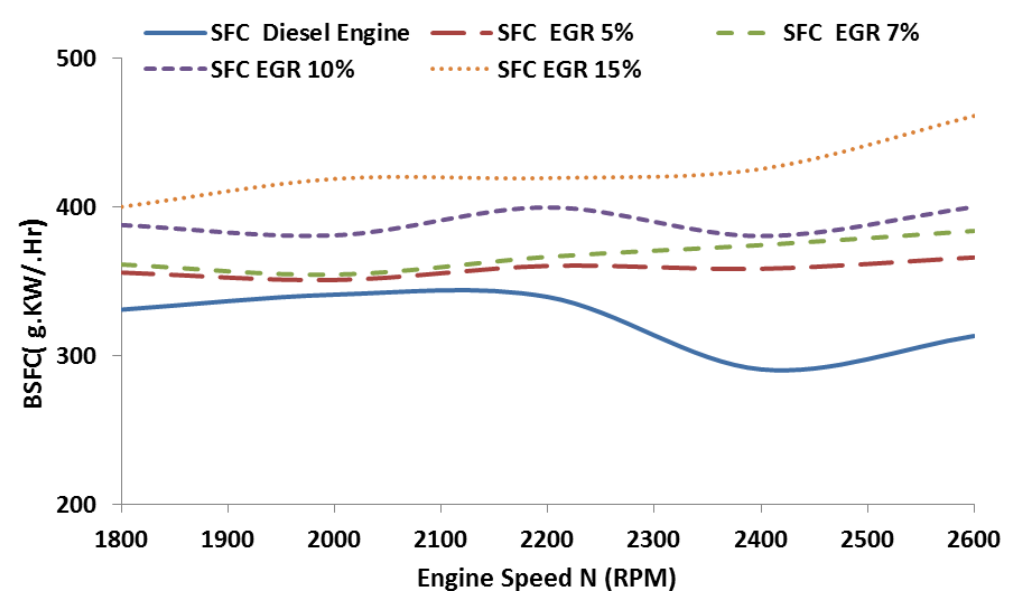

(c)

Figure 5. (a) Torque, (b) brake power, (c) BSFC and load at different engine speeds fuelled with diesel fuel with and without EGR.

The EGT in this engine decreased when EGR system was used, while the highest EGT was observed when EGR was not used, which is in agreement with the study by Manieniyan [6] demonstrating that when using EGR, the EGT was higher with biodiesel than normal diesel. The result of brake thermal efficiency (BTE) showed the difference of brake thermal efficiency at different speeds (rpm) and EGR rates, which are presented in Figure 6(a). It shows the increase in BTE with decreased engine speed. The BTE reduced when EGR was used as shown in Figure 6(c). Additionally, the cylinder pressure reduces with increased EGR rates, hence affecting engine efficiency as a whole. On the other hand, the study by S. Jafarmadar and P. Nemati [20] revealed that when EGR rate from $0-30 \%$ was used, the efficiency was decreased from $42.2 \%$ to $14.0 \%$. In Figure $6(\mathrm{~b})$, the BMEP decreased as the EGR rate increases. This suggests that the engine has less work to produce whenever the BMEP reduces.

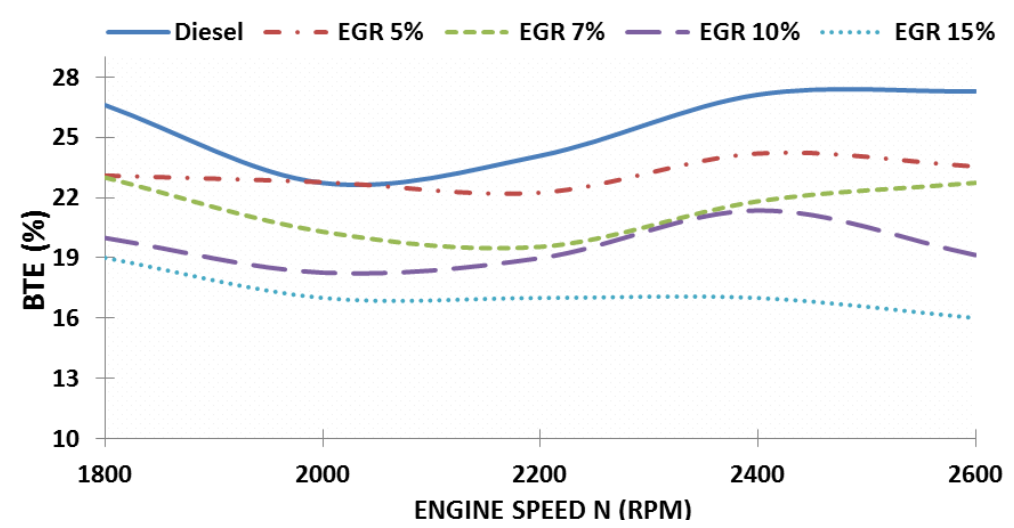

(a) 


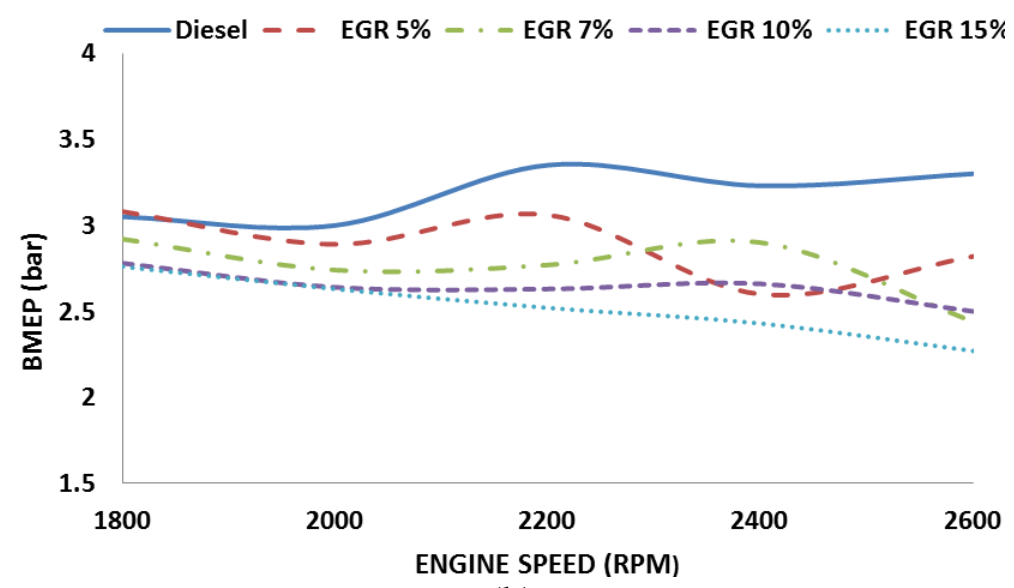

(b)

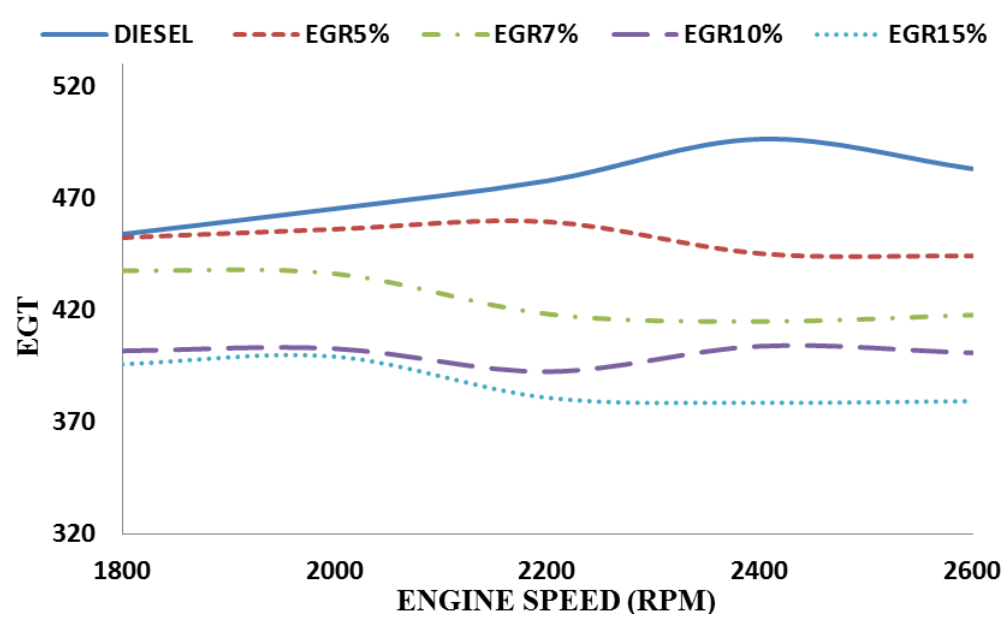

(c)

Figure 6. (a) BTE, (b) BMEP and; (c) EGT at different engine speeds fuelled with diesel fuel with and without EGR.

\section{CONCLUSION}

This study has shown the results of improved diesel engine performance and reduced emission using diesel engine running with EGR rates $(5 \%, 7 \%, 10 \%$, and 15\%). EGR with diesel fuel in this study has been employed to measure the suitability of diesel engine in evaluating the engine efficiency and its performance. The engine performance has been calculated as BTE and SFC in three tests with EGR and compared with diesel engine. The BTE with EGR was found lower than engine without EGR.

In the emission case, $\mathrm{CO}_{2}, \mathrm{CO}, \mathrm{NO}_{\mathrm{x}}$ and $\mathrm{UHC}$ amounts were shown in different engine speed (rpm) conditions. The EGR technique was seen to decrease $\mathrm{NO}_{\mathrm{X}}$ production. Other emissions including $\mathrm{HC}$ and $\mathrm{CO}$ were immediately decreased with the use of EGR. Thus, the EGR system can be suitably used to reduce $\mathrm{NO}_{x}$ emission level. Meanwhile, in the engine's test results, it has been determined that EGR and normal engine have increased SFC and decreased the engine performance including power and torque. The cylinder pressure with EGR at full load was seen lower, resulting in a lower BTE when the engine operated with EGR. 


\section{ACKNOWLEDGEMENT}

The authors would like to thank Universiti Putra Malaysia for providing research facilities and grant. The study is supported by GP-IPM research grant from UPM with project code GP-IPM 9483100. Besides, the authors would like to thank the supervisor and cosupervisor for their support and guidance.

\section{REFERENCES}

[1] Rajesh Kumar B, Saravanan S. Effect of exhaust gas recirculation (EGR) on performance and emissions of a constant speed di diesel engine fueled with pentanol/diesel blends. Fuel 2015; 160: 217-226.

[2] Mardi K M, Khalilarya S, Nemati A. A numerical investigation on the influence of EGR in a supercharged SI engine fueled with gasoline and alternative fuels. Energy Conversion and Management 2014; 83: 260-269.

[3] Hussain J, Palaniradja K, Alagumurthi N, et al. Effect of Exhaust Gas Recirculation (EGR) on Performance and Emission of a Compression Ignition Engine with Staged Combustion (Insertion of Unburned Hydrocarbon). International Journal of Energy Engineering 2012; 2: 285-292.

[4] Zala MR. Optimization of EGR Rate on multi cylinders 4 - stroke diesel engine. International Journal of Engineering Research \& Technology 2012; 1: 1-7.

[5] Hebbar GS, Bhat AK. Academic @ Paper Investigations on Performance and Emissions of a Stationary DI Diesel Engine with Different Exhaust Gas Recirculation Temperatures. International Journal of Automotive Engineering and Technologies 2013; 1-9.

[6] Manieniyan V, Sivaprakasam S. Experimental Analysis of Exhaust Gas Recirculation on DI Diesel Engine Operating with Biodiesel. International Journal of Engineering and Technology 2013; 3: 129-135.

[7] Pandhare AP, Zende KC, Joglekar a. S, et al. Effect of EGR on the Exhaust Gas Temperature and Exhaust Opacity in Compression Ignition Engines Using Jatropha Oil as Fuel. Applied Mechanics and Materials 2011; 110-116: 431-436.

[8] Dhana Raju V, Kishore PS. Effect of exhaust gas recirculation on performance and emission characteristics of a diesel engine fuelled with tamarind biodiesel. International Journal of Ambient Energy 2018; 7269: 1-30.

[9] Jagadish D, Kumar DPR, Murthy DKM. Performance Characteristics of a Diesel Engine Operated on Biodiesel With Exhaust Gas. International Journal of Advanced Engineering Technology; 2011; 2(2): 0976-3945.

[10] Paykani A, Akbarzadeh A, Tabar MTS. Experimental Investigation of the Effect of Exhaust Gas Recirculation on Performance and Emissions Characteristics of a Diesel Engine Fueled with Biodiesel. IACSIT International Journal of Engineering and Technology 2011; 3: 239-243.

[11] Huang H, Zhou C, Liu Q, et al. An experimental study on the combustion and emission characteristics of a diesel engine under low temperature combustion of diesel/gasoline/n-butanol blends. Applied Energy 2016; 170: 219-231.

[12] Saravanan S. Effect of higher injection pressure on performance and emission characteristics of a stationary diesel engine at retarded injection timing. International Journal of Oil, Gas and Coal Technology 2015; 10: 115-124.

[13] Yasin MHM, Mamat R, Yusop AF, et al. Study of a Diesel Engine Performance with Exhaust Gas Recirculation (EGR) System Fuelled with Palm Biodiesel. 
Energy Procedia 2017; 110: 26-31.

[14] Wankhade AM, Thakare SB, Sapre PG. Emission Characteristics for Single Cylinder DI Diesel Engine with EGR (Exhaust Gas Recirculation) System. International Journal of Engineering Sciences \& Research Technology, 2014; 3(9): 315-323.

[15] Semakula M, Inambao PF. The Effects of Exhaust Gas Recirculation on the Performance and Emission Characteristics of a Diesel Engine - A Critical Review. 2017; 12: 13677-13689.

[16] Rajan K, Kumar KRS. Effect of Exhaust Gas Recirculation (EGR) on the Performance and Emission Characteristics of Diesel Engine with Sunflower Oil Methyl Ester. International Journal of Chemical Engineering Research 2009; 1: 31-39.

[17] Akihama K, Takatori Y, Inagaki K, et al. Mechanism of the Smokeless Rich Diesel Combustion by Reducing Temperature. 2001. Epub ahead of print 2001. DOI: 10.4271/2001-01-0655.

[18] Verschaeren R, Schaepdryver W, Serruys T, et al. Experimental study of NOxreduction on a medium speed heavy duty diesel engine by the application of EGR (exhaust gas recirculation) and Miller timing. Energy 2014; 76: 614-621.

[19] Sunil Naik N, Balakrishna B. Effects of EGR on performance and emissions of a diesel engine fuelled with balanites aegyptiaca/diesel blends. International Journal of Sustainable Engineering 2018; 11: 150-158.

[20] Jafarmadar S, Nemati P. Analysis of Exhaust Gas Recirculation (EGR) effects on exergy terms in an engine operating with diesel oil and hydrogen. Energy 2017; 126: 746-755. 